\title{
KH. ZAINAL MUSTHAFA'S STRUGGLE IN DEVELOPING THE NATION'S INTELLECTUAL LIFE
}

\section{Tatang Hidayata, and Aam Abdussalamb}

Indonesia University of Education, Bandung

email: atatanghidayat@upi.edu, baam100@upi.edu

\begin{abstract}
Many national independent struggle movements in Indonesia began from traditional Islamic boarding schools (pondok pesantren). One of the the movements was established by $\mathrm{KH}$. Zainal Musthafa of Tasikmalaya, West Java. This study aims to examine this scholar's struggle of independence and his spirit in developing the nation's intellectual life. Based on interview and historical archives, this study shows that KH. Zainal Musthafa plays a vital role in the independence struggle. He was a role model, who was not only a Muslim religious scholar ('ulama'), but also a fighter against colonialism. His struggle was motivated by the values and principle of tawhìd (Oneness of God) and the spirit of Indonesian independence. His struggle furthermore departed from and was shaped by, the teachings offered at traditional Islamic boarding school. This suggests that traditional Islamic educational system, spiritualism and mode of Islamic religiosity developed by pesantren constitute one of the most relevant aspects of Islam in the struggle for Independence and, as this paper argues, remain relevant to the contemporary Indonesian spiritual and intellectual life. It is through pesantren and their leaders that Islamic spiritualism and public intellectualism have thrived up to the present.
\end{abstract}

Keywords: KH. Zainal Musthafa, Pesantren, Nation's spirit, Struggle, Value

DOI: https://doi.org/10.20414/ujis.v23i2.363

\section{Introduction}

PONDOK PESANTREN or Islamic religious, educational institutions in Indonesia have been established since the spread of Islam in the archipelago in the $15^{\text {th }}$ century AD. Maulana Malik Ibrahim (d. 
1419), one of the nine saints (Wali Songo), was believed to be the first leading person to establish pesantren, which was used as a centre of Islamic propagation and learning. ${ }^{1}$ In the subsequent developments, the most successful leading person in the development of pesantrens was Sunan Ampel (Raden Rahmat), also the son of Maulana Malik Ibrahim, who later established several other Wali Songo pondok pesantrens, such as Pesantren Giri, Pesantren Demak, Pesantren Tuban, Pesantren Derajat, and others in Nusantara. ${ }^{2}$ Accordingly, pesantrens are the oldest Islamic educational institutions in Indonesia that have contributed greatly to the development of the country's human resources.

The existence of pesantrens continues to be recognized from time to time, starting from the colonial to independence period. One of the leading figures from pesantren is Kyai Haji (KH.) Zainal Musthafa. He was involved in developing the nation's intellectual life, fostering good character, defending religion and nation from invaders. ${ }^{3}$ In the $21^{\text {st }}$ century, the role of pesantren is not only concerned with an educational institution, ${ }^{4}$ but also with religious, economic, and social development. Pesantrens have developed into agents of change and community development, ${ }^{5}$ although its core business concerns teaching and learning of Islamic subjects. ${ }^{6}$

In the past, especially during the independence struggle, pesantren were involved in a physical fight against the colonialists

1 Musthofa, "Kedatangan Islam dan Pertumbuhan Pondok Pesantren di Indonesia Perspektif Filsafat Sejarah," An-Nuha 2, no. 1 (2015): 1-15.

2 Saeful Anam, "Karakteristik dan Sistem Pendidikan Islam: Mengenal Sejarah Pesantren, Surau, dan Meunasah di Indonesia," Jalie: Journal of Applied Linguistics and Islamic Education 1, no. 1 (2017): 146-149.

${ }^{3}$ Syeh Hawib Hamzah, "Perkembangan Pesantren di Indonesia," Syamil 2, no. 1 (2014): 1-14.

4 Tatang Hidayat, Ahmad Syamsu Rizal, and Fahrudin, "Peran Pondok Pesantren Sebagai Lembaga Pendidikan Islam di Indonesia," Ta'dib: Jurnal Pendidikan Islam VII, no. 2 (2018): 1-15.

${ }^{5}$ Izzuddin Musthafa, Dedih Wahyudin, and Betty Tresnawaty, "The People Empowerment Pattern In Pesantren Environment: A Case Study about Community Around Pesantren in West Java, Indonesia," Advances in Social Science, Education and Humanities Research 143, no. November (2017): 53-33.

6 Ismail Suardi Wekke and Sanusi Hamid, “Technology on Language Teaching and Learning: A Research on Indonesian Pesantren," Procedia - Social and Behavioral Sciences 83 (2013): 585-589. 
and served its building as the bulwark against foreign invasion. Kiai (pesantren leaders) and santri (students of pesantrens) worked for hand in hand along with other elements of society in the country to defend the homeland from the foreign occupation. However, the national history and the politics of historiography only record the pesantren's independent struggle disproportionally. ${ }^{7}$ The official history lack of the pesantren's voice. As a result, the role of the kiai, and pesantren in leading the national movement are hardly recognized by the Indonesian younger generation. ${ }^{8}$

Due to little literature on this theme, the roles of kiai and pesantren in fighting for Indonesian independence are almost not recognized, especially the literature that explains local-based independence struggle. ${ }^{9}$ This study thus attempts to fill this gap. Learning local history is very important to attain local wisdom through local figures or events. As a result, people are expected to be attentive to their environment, respect cultural diversity, and recognize their identity. ${ }^{10}$ Many of the local independence struggle events became the forerunner of Indonesian independence, especially pesantrens led by kiai. The independence struggle that took place in Tasikmalaya, West Java, as one of the famous local events, still escapes the attention of the younger generation.

Tasikmalaya is one district in West Java and is known as the city of santri. Tasikmalaya has many formal and informal religious education institutions. ${ }^{11}$ One of the biggest and famous pesantrens

7 On a similar critique, see Mohamad Abdun Nasir, "Islam, Historical Representation and Muslim Autobiography in the Indonesian New Order," Studia Islamika 18, no. 1 (2014): 67-100.

${ }^{8}$ Ahmad Mansyur Suryanegara, Api Sejarah 2 (Bandung: Salamadani, 2014).

${ }_{9}$ Anwar Nuryamin, "The Uniqueness of the Pesantren KH. Zainal Musthafa Sukamanah Tasikmalaya in Islamic Boarding School Education Organize," March 27, 2019.

10 Yanyan Hardiana, "Pembelajaran Sejarah Indonesia Berbasis PeristiwaPeristiwa Lokal di Tasikmalaya untuk Meningkatkan Kemampuan Berpikir Kritis," Historia: Jurnal Pendidik dan Peneliti Sejarah I, no. 1 (2017): 41-46.

${ }^{11}$ Ima Amaliah, Tasya Aspiranti, and Pupung Purnamasari, “The Impact of the Values of Islamic Religiosity to Islamic Job Satisfaction in Tasikmalaya West Java, Indonesia, Industrial Centre," Procedia - Social and Behavioral Sciences 211, no. September (2015): 984-991. 
in Tasikmalaya is Pondok Pesantren Sukamanah, led by $\mathrm{KH}$. Zainal Musthafa. This pesantren was one of the many Islamic schools that took an active part in the struggle for Indonesian independence. By studying and exploring various local struggles, this study is expected to offer an account of the struggle of independence and examine the values, experience and spirit of the kiai and their santri in realizing this golden goal.

Combining a mixed method, ${ }^{12}$ this research was conducted at Pondok Pesantren KH. Zainal Musthafa Sukamanah Tasikmalaya. The data were gathered through interviews with key informants, especially the kiai's close family, the current pesantren leaders and santri. This study also collected public open data about the pesantren and its founder. One important document of this study is a film of Asy-Syahid KH. Zainal Musthafa and discussions with experts about the film that are relevant to research theme.

\section{The Biography and Work of KH. Zainal Musthofa}

Zainal Musthafa was born in Kampung Bageur, Cimerah Kewedanaan Village, Singaparna, Tasikmalaya District (now Sukarapih Village, Sukarame Sub-district, Tasikmalaya District) in 1901. His mother was Ratmah and his father was Nawapi. His childhood nicknames were Umri and Hudaemi. He grew up in a humble and religious farmer family. ${ }^{13}$ It is believed that the kiai is the descendant of the Mataram Islam Javanese Kingdom or has a close relationship with it. The kiai's grandchildren stored an heirloom of sword inherited from the Islamic Mataram Kingdom. ${ }^{14}$

12 Tatang Hidayat and Abas Asyafah, "Paradigma Islam dalam Metodologi Penelitian dan Implikasinya terhadap Penelitian Pendidikan Agama Islam," Tadrib IV, no. 2 (2018): 225-245.

${ }^{13}$ Fuad Muhsin, Sekilas Riwayat Hidup dan Perjuangan Pahlawan Nasional AsySyahid KH. Zainal Musthafa (Tasikmalaya: Pondok Pesantren Sukamanah Tasikmalaya, 2010).

${ }_{14}$ Yusuf Hazim, "Interview: Riwayat Hidup Pahlawan Nasional KH. Zainal Musthafa" (Tasikmalaya, 2017). 


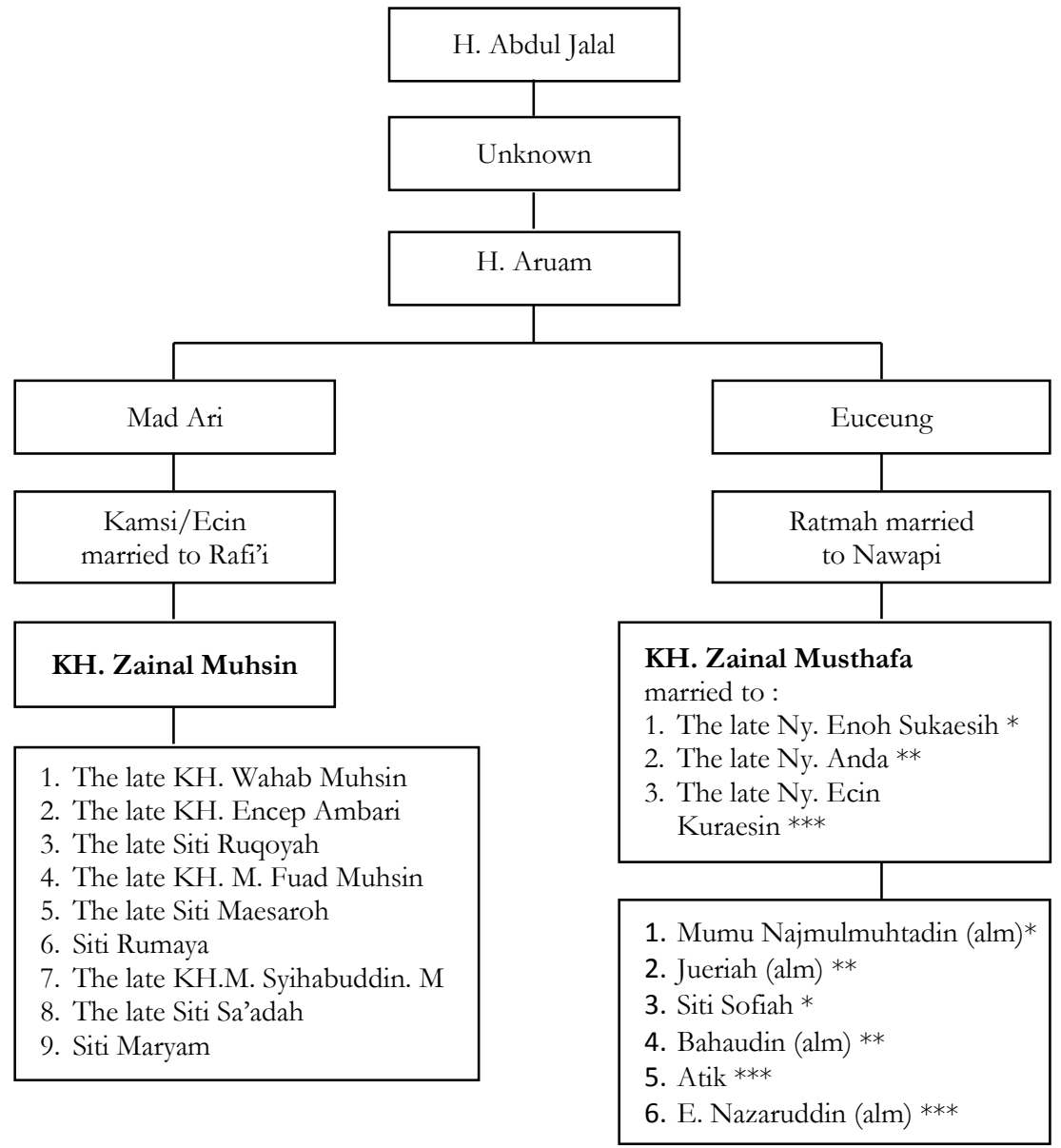

Chart 1. Lineage of KH. Zainal Musthafa. ${ }^{15}$

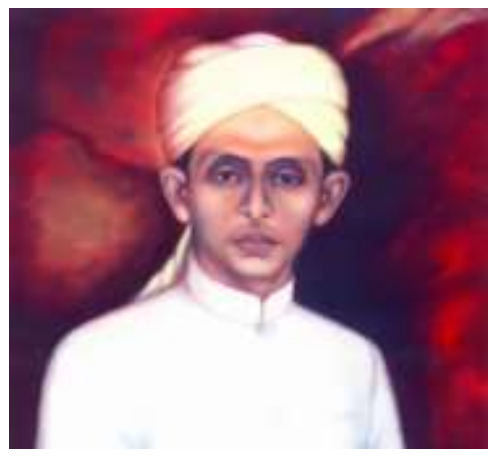

Figure 1. K.H. Zainal Musthafa ${ }^{16}$

${ }^{15}$ Muhsin, Sekilas Riwayat Hidup. 
After Zainal Musthafa graduated from Sekolah Rakyat, he studied at several pesantrens, namely: Pesantren Gunung Pari (7 years), Pesantren Cilenga Leuwisari (4 years), Pesantren Sukaraja Garut (3 years), Pesantren Sukamiskin Bandung (3 years), and Pesantren Jamanis Rajapolah (1 year). At the Pesantren Gunung Pari he was mentored by his older brother Dimyati who later known as KH. Zainal Muhsin. ${ }^{17}$

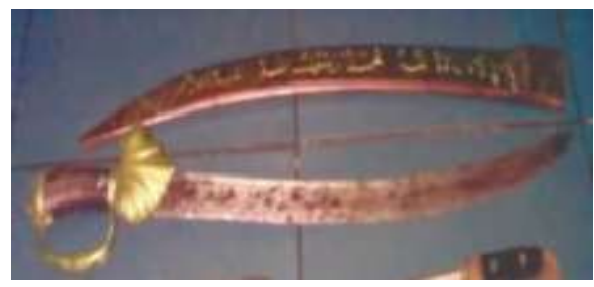

Figure 2. Sword of the Islamic Mataram Kingdom. ${ }^{18}$

In 1927, Zainal Musthafa established a pesantren in Cikembang and named it Pesantren Sukamanah. Cikembang village changed its name into Sukamanah village. Pesantren Sukamanah was established on a plot of the waqf land for houses and mosques from a generous widow named Hj. Juariyah. Previously, in 1922 $\mathrm{Hj}$. Juariyah gave the same waqf land to Zainal Muhsin (Founder of Pesantren Sukahideng) in Kampung Bageur. At a very young age, namely 26 years of age, Zainal Musthafa established a pesantren, and performed the pilgrimage in 1928 which was also funded by Hj. Juariyah. ${ }^{19}$

As an Islamic cleric ('ulamā') KH. Zainal Musthafa holds the characters of $t \bar{a}^{\prime} a h$ (obedient), steadfast, qan $\bar{a}$ 'ah (contentment), shaja'ah (determined), and the values of honesty, truth and justice. With such characters, he inevitably becomes a leader and role model of a charismatic, patriotic, virtuous and visionary people. ${ }^{20}$ This was proven by his coalition with the Jam'iyyah Nahdlatul

16 “Gambar KH. Zainal Musthafa” (Tasikmalaya, 2017).

${ }^{17}$ Hazim, "Riwayat Hidup."

18 Pedang Peninggalan Kerajaan Mataram Islam (Tasikmalaya: Tidak dipublikasikan, 2017).

${ }^{19}$ Muhsin, Sekilas Riwayat Hidup.

20 Acep Wahid, "Perjuangan Pahlawan Nasional KH. Zainal Musthafa (Wawancara Bersama Acep Wahid)" (Tasikmalaya, 2017). 
Ulama (NU) in 1933. He was listed as Deputy of Rois Syuriyah NU Tasikmalaya Branch ${ }^{21}$ and later resigned. ${ }^{22}$

There were around 700 students registered at the Pesantren Sukamanah during the pre-independence time. This was a quite big pesantren that potentially challenged the colonial authority. Therefore, this fact raised great suspicion for the Dutch government. They assumed that the teaching activities conducted at the pesantren were an association intended to compile the strength of the Indonesian people against the invaders. ${ }^{23}$ While giving $d a^{\prime}$ wah (preaching), KH. Zainal Musthafa was often banned by the accomplice of the Dutch government and detained in the Tasikmalaya prison with KH. Ruhiyat (Leader of Pesantren Cipasung) on November 17, 1941 M / 27 Syawal 1362 H on charges of inciting the people. A day later, they were transferred to Sukamiskin prison in Bandung, and released on January 10, 1942. KH. Zainal Musthafa was arrested again and detained in Ciamis prison in late February 1942 before the Japanese invaded Java and was released by a Japanese colonel on March 31, 1942. ${ }^{24}$

Although the domination had been released from the Dutch colonial to the Japanese army, KH. Zainal Musthafa's attitude and viewpoint against the new invaders did not change. His hatred was even mounting after witnessing the Japanese colonial's tyranny upon Tennohaika servants. Thousands of Indonesians were made to be at workplace romusha. The new colonial also took people's possession and properties, levying high taxes and other inhuman treatment. Moreover, every morning they also forced the people to perform saikeirei, or bowing to the Japanese Emperor's palace in Tokyo. He refused the Japanese's command and decided to oppose the colonial and launched a holy war (jihad) against them even though his life was at stake. ${ }^{25}$

${ }^{21}$ Muhsin, Sekilas Riwayat Hidup.

22 Hazim, "Riwayat Hidup."

${ }^{23}$ Muhsin, Sekilas Riwayat Hidup.

${ }^{24}$ Adeng, "Pesantren Cipasung di Bawah Kepemimpinan K.H. Ruhiat (Studi Keterlibatan Kiai Dalam Perjuangan Kemerdekaan)," Patarjala 6, no. 2 (2014): 253268.

${ }^{25}$ Muhsin, Sekilas Riwayat Hidup. 
The Japanese army began noticing the opposition attitude of KH. Zainal Musthafa when the Dai Nippon Government gathered all ulama and ajengan in Singaparna credentials to perform saikeirei by lowering half of the body towards Tokyo at the gunpoint of the Japanese police. He was the only ulama who refused to do saikeirei. According to him, the act was one form of worships which could damage the Islamic faith. ${ }^{26}$

After that incident, KH. Zainal Musthafa began to be supervised by the Japanese government. He was convinced that it was the right time to hold a resistance, rebelled against the Japanese tyranny. Rebelling means listening to the wailing of the Indonesian people who were languished, humiliated, insulted, raped, and trampled under the soles of other peoples' feet. At the beginning of 1943, the conceptual plan for resistance to the Japanese military was compiled globally, dividing into two parts, namely short-term plans and long-term plans. ${ }^{27}$

The short-term plan was to secretly foster the mentality of the santri by cultivating the values of tawhìd and rụh al-jihäd as well as physical preparation with the formation of a combat unit (Voluntary Battalion Sukamanah) consisting of the Sukamanah santri itself. The long-term plan was to take a positive part in the national revolution that was being prepared by Indonesian political figures in Jakarta. ${ }^{28}$

Until the end of 1943, the Sukamanah Voluntary Battalion had been completely prepared, and at the same time, a War Council and the Sukamanah People's Defense Area were arranged. The organizational structure of the Sukamanah Movement can be described as follows:

${ }^{26}$ Nurul Haki and Suhartono, "Perubahan Sosial Pesantren di Tasikmalaya Pada Paruh Pertama Abad Ke-20 (1905-1950)," Jurnal Humanika 17, no. 3 (2004): 341-354.

${ }_{27}$ Syarief Hidayat, Kisah Nyata Sebelum dan Sesudah Indonesia Merdeka Riwayat Perjuangan dari Pemberontakan Sukamanah sampai Prajurit Sapta Marga (Tasikmalaya: Dinas Dikbud SLTP KHZ Musthafa, 1996), 73-74.

${ }^{28}$ Hidayat, Kisah Nyata. 


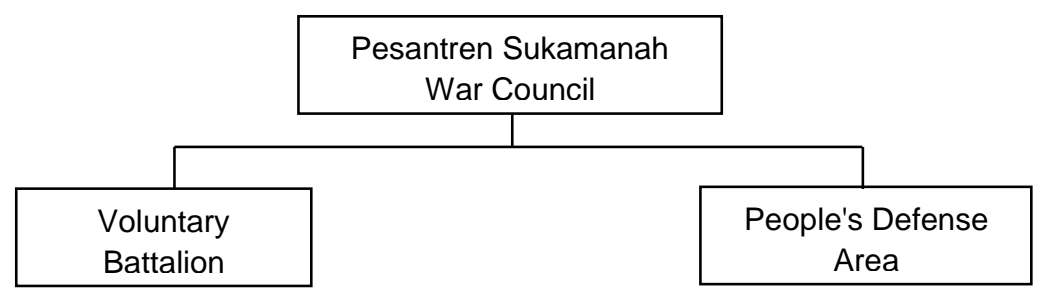

Chart 2. The Sukamanah Movement Organization. ${ }^{29}$

\begin{tabular}{ll}
\hline $\begin{array}{l}\text { The organizational structure of the Sukamanah Movement } \\
\text { War Council }\end{array}$ \\
\hline Chairman & KH. Zainal Musthafa \\
\hline Vice Chairman & Kiai Domon \\
\hline Member & Kiai Aip Abdul Hakim \\
\hline Member & Kiai Hambali \\
\hline Member & Kiai Nadjmuddin \\
\hline Member & Kiai H. Hidayat \\
\hline Member & Kiai Saefuddin \\
\hline
\end{tabular}

Table 1. The organizational structure of the Pesantren Sukamanah War Council. ${ }^{30}$

The Voluntary Sukamanah Battalion consisted of 1 Battalion Staff, and 5 Combats under the leadership of Kiai Najdmuddin. The People's Defense Region was arranged in a horizontal scale of 2.5 KM with Pesantren Sukamanah as the central point, divided into four districts and under the leadership of Haji Hidayat. ${ }^{31}$

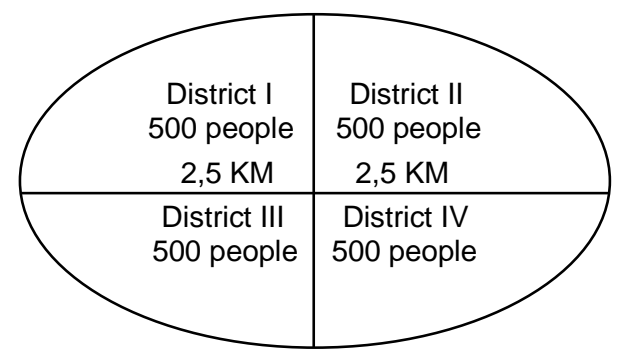

Figure 3. The People's Defense Region. ${ }^{32}$

\footnotetext{
${ }^{29}$ Ibid.

${ }^{30}$ Ibid., 79.

${ }^{31}$ Ibid., 79-80.

${ }^{32}$ Hidayat, Kisah Nyata.
} 


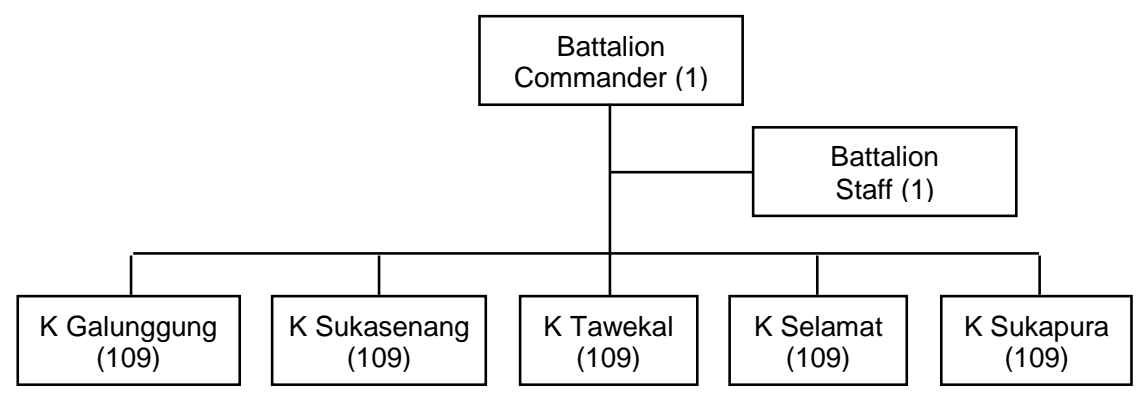

Chart 3. Organizational Structure of Sukamanah Voluntary Battalion. ${ }^{33}$

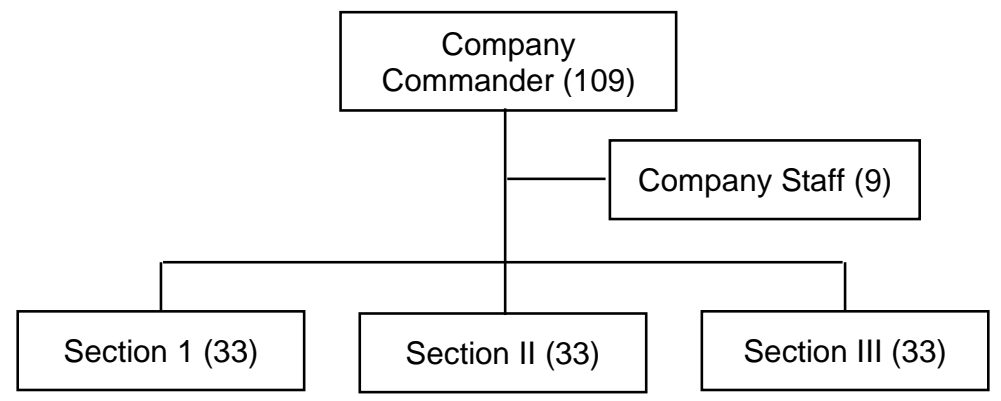

\section{Chart 4. Organizational Structure of Sukamanah Islamic Voluntary Battalion Company. ${ }^{34}$}

After the Voluntary Sukamanah Battalion was formed, in turn, each team got the task to carry out the security of the Pesantren Sukamanah complex. Meanwhile, all activities in the Pesantren Sukamanah and its surrounding areas were continuously monitored and investigated by kenpeitai (Japanese military police) and Japanese Intelligence officers. In Tasikmalaya, since the end of 1943, the Kenpeitai had actually intended to capture KH. Zainal Musthafa. However, they always failed to persuade him to face the kenpeitai office. Courier after courier, letter after letter were sent to Sukamanah from the regent (kenco), the resident (syucokan) and from kenpeitai himself. The letters were never replied, not even addressed at all, except one letter received around February 1, 1944. It was an official invitation from the kenpeitai commander of Tasikmalaya for KH. Zainal Musthafa, Kiai Domon, and Kiai Aip

\footnotetext{
${ }^{33}$ Ibid.

${ }^{34}$ Ibid., 81.
} 
Abdulhakim to come. The answer to the letter was sent by post with a short notice of refusal to the invitation. ${ }^{35}$

The spirit of struggle and self-esteem had been embedded within the Sukamanah fighters. They already had a fighter personality; therefore, the Sukamanah Fighters only wanted to surrender through the procedure of heroes. The Pesantren Sukamanah War Council on February 3, 1944, at the early evening formulated an attack strategy and ordered Commander Nadjmuddin to increase training activities for unexpected attack and ambush. On February 5, 1944, all santris and the people of Sukamanah were armed. Everyone was equipped with a bamboo sword which their shape and size outlined by the commander. ${ }^{36}$

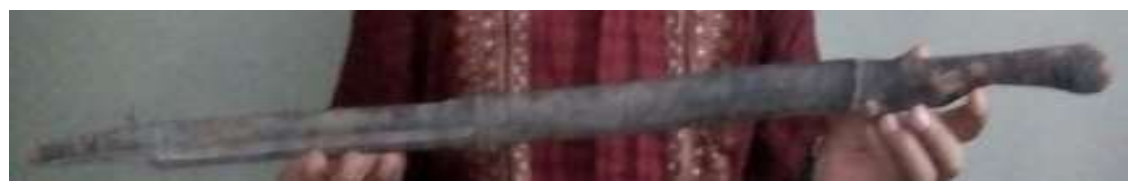

Figure 4. KH. Zainal Musthafa's Bamboo Sword Forces. ${ }^{37}$

On Wednesday, February 23, 1944, the Japanese army sent an envoy to the pesantren. They threatened $\mathrm{KH}$. Zainal Musthafa and his students were stating that if until Monday, February 28, 1944, he did not surrender, they would destroy the pesantren. Not until Monday, it turned out the next day, Thursday, February 24, 1944, Japan deployed kenpeitai troops, led by local officials who were on their side, such as Head of Chakra Wilaksana, Sastramaun (Head of Cimerah Village), Suhandi (Clerk), and Muhri (Head of Kampung Punduh). Their only goal was to arrest KH. Zainal Musthafa. Nevertheless, one team from the Japanese kenpeitai army failed to capture $\mathrm{KH}$. Zainal Musthafa and they became detainees in Sukamanah. ${ }^{38}$

${ }^{35}$ Hidayat, Kisah Nyata.

${ }^{36}$ Ibid., 90-91.

37 Yusuf Hazim, Pedang Bambu Peninggalan Pasukan KH. Zainal Musthafa (Tasikmalaya, 2017).

38 Abdi Muaffan, “Singa Tasikmalaya," Www.Pstkhzmusthafa.or.Id (Tasikmalaya, 2018). 
On the night before facing the battle, $\mathrm{KH}$. Zainal Musthafa stayed in a mosque, and some of the santri's weapons, including the bamboo swords, were presented to him to be given some dhikr and prayers. One of the chanting he recited was derived from the verse of the Quran: ${ }^{39}$

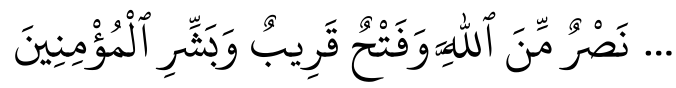

... victory from Allah and an imminent conquest; and give good tidings to the believers. (QS. al-Ṣaf [61] : 13). ${ }^{40}$

In the next day, Friday, February 25, 1944, all detainees were released. At around 1:00 p.m., when the Friday prayers were still ongoing, four kenpeitai arrived. One of them was an interpreter. They conceitedly asked KH. Zainal Musthafa to surrender and asked their weapons to be returned. The weapons were 12 rifles, three pistols, and 25 sharp weapons. KH. Zainal Musthafa, along with the santri met and negotiated with them. Suddenly, a kenpeitai pointed a gun at $\mathrm{KH}$. Zainal Musthafa. This provoked the students of Sukamanah and the surrounding community, who were fearless of death, responding it with a shriek of takbir and immediately attacked them. Three kenpeitai and an interpreter ran to the rice fields and 3 of them died there while one of them escape. $^{41}$ A santri from sukamanah named Nurul Fuad (Sukasenang Company Commander) fell on the battlefield due to gunfire right on his head as he chased a kenpeitai who escaped through Cihaur. ${ }^{42}$ In another opinion, a kenpeitai was left free to report to their commander. ${ }^{43}$

They were knowing that the pesantren will be attacked, $\mathrm{KH}$. Zainal Musthafa gave freedom of choice to the santri if they chose to resign or go back to their respective villages. However, all the santris chose to take part in the fight. Except for a few santri who were chosen by the kiai not to go such as KH. A Wahab Muhsin

\footnotetext{
39 "Film Asy-Syahid KH. Zainal Musthafa," Www.Pstkhzmusthafa.or.Id.

40 “Aplikasi Quran in Word Versi 64 - 3.0," 2018.

${ }^{41}$ Muhsin, Sekilas Riwayat Hidup.

${ }^{42}$ Hidayat, Kisah Nyata, 104.

${ }^{43}$ Hazim, "Riwayat Hidup."
} 
(successor of Pesantren Sukahideung), KH. Fuad Muhsin (successor of Pesantren Sukamanah), and others. ${ }^{44}$

Near late afternoon time, six special police companies came from all over West Java. It turned out that they were the soldiers of the Indonesian people themselves who immediately opened the salvo and showered the rows of santri who were only armed with sharp bamboos, bamboo swords, and other simple weapons. Realizing that they were people from the same nation, $\mathrm{KH}$. Zainal Musthafa gave the command not to fight before they entered the fighting area. When they were approaching, the sharp bamboos, bamboo swords, and machetes were utilized to fight back the attack. With such high strength, a great war strategy, and equipped with sophisticated weaponry, the Japanese army managed to break through and destroy the defence of Sukamanah forces and arrest K.H. Zainal Musthafa. ${ }^{45}$

It is important to note that actually in the battle $\mathrm{KH}$. Zainal Musthafa was not in the front row. Instead, he commanded the troops from behind after knowing that some opponents who were killed were Indonesian. KH. Zainal Musthafa worried if the killed opponents still established salat (prayer) so that he instructed his troops to stop fighting and surrender. It was then discovered after the battle that 300 Japanese were killed. The number was obviously greater than the number of victims of Sukamanah troops which were 86 people. ${ }^{46}$

The Sukamanah fighters avoid mentioning the names of other people in their respective stories except for KH. Zainal Musthafa and those who died on the battlefield. They were also instructed to never claim to kill, hit, touch, or see any Japanese army and never admit to participating in the battle, let alone taking office in the Sukamanah Voluntary Battalion. ${ }^{47}$ If they were forced, they should say that they only know one of his students, letting KH. Zainal Musthafa to bear any risks of the battle. ${ }^{48}$ Furthermore, the santri and other followers were also taught that if the Japanese army

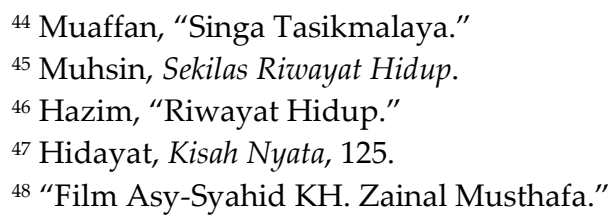


caught and interrogated them, they should say they were deceived by KH. Zainal Musthafa to liberate Indonesia. By saying that they were deceived by a kiai and it was expected that his santris who were captured would not be brutally tortured by the kenpeitai of Japanese army. ${ }^{49}$

After the glory battle, KH. Zainal Musthafa was invited to negotiate by the Japanese army to discuss peace in Tasikmalaya. Nevertheless, that was just a trap. He was even arrested and tortured several times; being dragged using a truck from Padayungan to Kaum (Great Mosque of the Tasikmalaya City). However, he was not hurt at all, and this incident was the background to name the street where it happened with this kiai's name. KH. Zainal Musthafa himself underwent an interrogation process for three months. This interrogation was carried out with tortures; being punched and knocked down by a slender machine..$^{50}$

$\mathrm{KH}$. Zainal Musthafa was detained and imprisoned in Tasikmalaya then he was transferred to Bandung and Cipinang prison. After that, his position was unknown. According to Kol. Drs. Nugraha Natosusanto, Head of the ABRI History Center, on March 23, 1970, it was revealed that according to the head of the Dutch Ereveld (Park of Heroes) office, KH. Zainal Musthafa was received a death penalty, on October 25, 1944, and was buried in Dutch Heroes Park Ancol, Jakarta. ${ }^{51}$

KH. Zainal Musthafa was awarded the title of "National Hero" with the reference of President of the Republic of Indonesia Number: 064 / TK in 1972 dated November 20, 1972, submitted by Mintareja SH the social minister to the family of $\mathrm{KH}$. Zainal Musthafa on January 9, 1973. Later on, the corpse's martyr KH. Zainal Musthafa along with 17 of his santris were transferred to the Sukamanah Heroes Park on August 25, 1973. ${ }^{52}$

\footnotetext{
49 Suryanegara, Api Sejarah 2.

${ }^{50}$ Hazim, "Riwayat Hidup."

${ }^{51}$ Muhsin, Sekilas Riwayat Hidup.

${ }^{52}$ Ibid.
} 


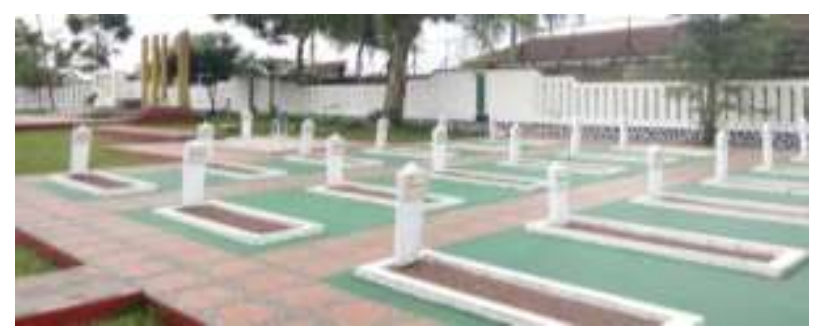

Figure 5. KH. Zainal Musthafa Heroes Park. ${ }^{53}$

In the process of transferring the remaining Ash-Shahid (the martyr) KH. Zainal Musthafa along with 17 of his santris (with cross-shaped tombs for camouflage) to Tasikmalaya, it was found that his body was still intact after 29 years of burial. When the remaining was lifted, he was in a sitting position on the nails installed by the Japanese army with his hands resting on his knees. Even the turban, clothes, and robe he wore were still intact, and the head was not separated. This discovery proved that $\mathrm{KH}$. Zainal Musthafa was not executed by being beheaded, instead, he was buried alive. ${ }^{54}$

KH. Zainal Musthafa had three wives, namely: The late Enoh Sukaenah (first wife), the late Anda (second wife), and the late $\mathrm{Hj}$. Ecin Kuraesin (third wife). They had six children, namely: The late Mumu Najmul Muhtadin, Siti Shofiyah (from the first wife), the late Jueriyah, the late Bahaudin, (from the second wife), $\mathrm{Hj}$. Atik Atikah and the late Drs. Endang Nazaruddin Musthafa (from the third wife). ${ }^{55}$

Singaparna Street was inaugurated as KH. Zainal Musthafa Street on February 25, 1960. Since 1974, every February 25 the Commemoration of the Struggle of National Heroes KH. Zainal Musthafa was held. Monument of the Struggle Actualization of KH. Zainal Musthafa Sukamanah at the Tasikmalaya By Pass roundabout was inaugurated on November 16, 2000 AD / 11 Sya'ban $1421 \mathrm{H}$ by the Governor of West Java. ${ }^{56}$

53 Dokumentasi Pribadi, Taman Makam Pahlawan KH. Zainal Musthafa Sukamanah (Tasikmalaya, 2017).

${ }^{54}$ Hazim, "Riwayat Hidup."

${ }^{55}$ Muhsin, Sekilas Riwayat Hidup.

${ }^{56}$ Ibid. 
KH. Zainal Musthafa Sukamanah's family became a member of the Indonesian National Heroes Family Association (IKPNI) and participated in the National Conference of IKPNI at the Kalibata National Heroes Park Building in Jakarta on August 7-9 $2008^{57}$

\section{The Role of KH. Zainal Musthafa in Developing Islamic Education Institutions}

The role of KH. Zainal Musthafa's in fostering Islamic education and his struggle against colonialism cannot be separated from the traditions and spiritual and moral values of the pesantren which he developed as the spirit of his struggle. Accordingly, the struggle of $\mathrm{KH}$. Zainal Musthafa in fighting all forms of tyranny is inseparable from the existence of pesantren as an Islamic educational institution. Therefore, he inevitably had a significant role in developing Islamic education, especially in Singaparna. The people of Tasikmalaya and West Java are already well acquainted with Pesantren Sukamanah as the basis of the struggle against the invaders in addition to be the place of Islamic scientific studies development. Pesantren Sukamanah produced many great Muslim religious scholars in Tasikmalaya and in West Java in general. $^{58}$

Pesantren Sukamanah serves the continuation of the spirit and struggle of its founders. ${ }^{59}$ In the past, $\mathrm{KH}$. Zainal Musthafa used to fight with weapons. In the present day, the struggle takes a different form or mode; It is to liberate the Indonesian people from slavery, poverty, destitution, occupation of the system, and to develop the nation's intellectual life.

\section{Pondok Pesantren and Intellectual Development}

The pesantren's is the legacy gory Sukamanah Battle events have passed. It occurred on Friday, February 25, 1944 AD / 1 Rabi'ul Awwal 1365 H, 86 fighters were martyred and buried in

${ }^{57}$ Ibid.

${ }^{58}$ Lukman Hakim, "Kifrah KH. Zenal Mustofa terhadap Perkembangan Pendidikan Islam di Sukamanah Singaparna Tasikmalaya," Tekno Efisiensi 2, no. 1 (2017): 137-142.

${ }^{59}$ Hidayat, Kisah Nyata, 254. 
one hole. KH. Zainal Musthafa passed away and left the Pesantren Sukamanah in ravaged. Later, KH. Moh. Fuad Muhsin (the younger brother of KH Wahab Muhsin) who married Siti Shofiyah (one of KH Zainal Musthafa's daughters) managed and rebuilt Pesantren Sukamanah in collaboration with K. Uha Abdul Aziz (the younger brother of KH. Zainal Musthafa) and assisted by KH. Zainal Musthafa's students who were still alive in $1950 .{ }^{60}$

Leaders of Pesantren Sukamanah and Sukahideng agreed to establish Sukahideng Islamic Elementary School (MI) in 1956, and establish Al Ishlah Junior High School (SMP) in 1958/1959. After the KH. Zainal Musthafa Sukamanah Foundation was formed on August 17, 1959, with notarial deed number 8 of 1959 and renewed with notarial deed number 10 of 1988, the MI, SMP, SMA, and PGAP changed into MI, SMP, SMA, PGAP K.H. Zainal Musthafa Sukamanah. ${ }^{61}$

In December 1999 KH. Fuad Muhsin handed over his leadership to his son Drs. KH. A. Thahir Fuad. The management of Pesantren Sukamanah and the schools under the auspices of the KH. Zainal Musthafa Sukamanah Foundation was assisted by all KH. Zainal Musthafa's family members and supporters based on their expertise and abilities. ${ }^{62}$

The basic philosophical foundation of Pesantren Sukamanah is to honour the religion of Allah. The pesantren was established as a stronghold of Islam which served to educate and foster the younger generation of Muslims to become religious and excellent figures. This also aimed to show the community the beauty and perfection of the Islamic teachings. In addition, the fundamental philosophical is also related to taking up arms, fostering a healthy generation, and understanding the true meaning of jihad in Islam. ${ }^{63}$

The pesantren's vision is to foster Muslims to possess akhläq alKarimah and scientific thinking based on the aqìdah of Ahlussunnah

${ }^{60}$ Muhsin, Sekilas Riwayat Hidup.

${ }^{61}$ Ibid.

62 Ibid.

63 Aris Risdiana, "Budaya Organisasi Pondok Pesantren Berbasis NU dan Persis Benda 67 di Tasikmalaya Jawa Barat," Aplikasia: Jurnal Aplikasi Ilmu-Ilmu Agama 16, no. 2 (2016): 73-83. 
wa al-Jamā'ah. As for the missions: First, is to possess the knowledge and akhlāq al-Karimah. Second, to instil an interest in science and good deeds. Third, is to be responsible for carrying out obligations. Fourth, to have a firm personality. Fifth, to be independent and humble. Sixth, to think visionary and revolutionary in a positive way. ${ }^{64}$ While the purposes of the pesantren are: First, to mould and provide an understanding of Islamic teachings. Second, to foster faith, piety, as well as science and technology. Third, to attain academic and non-academic success to make the pesantren excellent in terms of accomplishment. Fourth, to have personnel and staff professionals who are qualified in management and good at their service. Fifth, to prepare the students the ability and skill to merge into the community in accordance with the synergy of the government, parents and the community. ${ }^{65}$

To realize the missions of Pesantren Sukamanah, especially in fostering a generation with a good personality and akhlāq alkarimah, the akhlāq subjects are taught in every level of its education curriculum. The content of akhlāq learning almost reaches $80 \%$ of all subjects. This means that akhlāq education is not only given separately but also implemented in each lesson implicitly. The pesantren strives for integrating every program they hold to foster an attitude improvement in a Muslim's life. ${ }^{66}$

The santris' activities in the pesantren are fostered with various religious activities such as pengajian (recitation/lectures) with a fixed schedule and marhalah, congregation, tadarrus, recitation of dhikr al-Ma'thür, munadarah (discussion), tadrīb al-khuṭbah in four languages (Indonesian, Arabic, English, Sundanese), Qirä'at, learning the Qur'an (reading and writing), Arabic and English classes, Islamic cultural arts and sorogan. In addition to the formal activities, the santri were also facilitated to develop their talents in

${ }^{64}$ Brosur Pondok Pesantren KH. Zainal Musthafa Sukamanah (Tasikmalaya, 2017).

65 "Profil Pondok Pesantren KH. Zainal Musthafa Sukamanah Tasikmalaya," Www.Pstkhzmusthafa.or.Id.

${ }^{66}$ Risa Nopianti, "Pendidikan Akhlak Sebagai Dasar Pembentukan Karakter di Pondok Pesantren Sukamanah Tasikmalaya," Patanjala 10, no. 2 (2018): 251266. 
the fields of arts, sports such as volleyball, soccer, table tennis, badminton, santri gymnastics, and martial arts. ${ }^{67}$

To support the success in the learning process while creating a conducive atmosphere, the pesantren provides facilities such as mosques, offices, dormitories, madrasah, fields, sports equipment, art tools, cafeterias, poskestren, bathrooms, and other necessary infrastructure to support the activities of the santri while still promoting simplicity. ${ }^{68}$

\section{The actualization of KH. Zainal Musthafa's Struggle in Developing the Nation's intellectual life}

$\mathrm{KH}$. Zainal Musthafa was a religious figure who was also a fighter with strong Ghìrah Islammiyyah and nationality. KH. Zainal Musthafa struggled with the issue of aqidah (Islamic faith) robbery through the Japanese colonial's saikeirei, which was considered damaging the faith. ${ }^{69}$ Physical resistance to the compulsory saikeirei practice was carried out by KH. Zainal Musthafa and his followers on February 25, 1944 after Friday prayers. ${ }^{70}$ Based on the motives of his movement, it can be understood that $\mathrm{KH}$. Zainal Musthafa's rebellion was not motivated to demand the rice which had been seized by the Japanese army. In fact, at the time, people entrusted the pesantren with keeping their rice. $^{71} \mathrm{KH}$. Zainal Mushtafa's rebellion was more likely as a political resistance movement. He believed that if Indonesia was not colonized, the rice-seizing would not occur. Therefore, $\mathrm{KH}$. Zainal Musthafa gave the quality in his movement's motivation in demanding Indonesian independence. ${ }^{72}$

${ }^{67}$ Brosur Pondok Pesantren KH. Zainal Musthafa Sukamanah.

${ }^{68}$ Ibid.

${ }^{69}$ Lindra Darnela, "Tinjauan Sistem Hukum Dalam Penerapan Peraturan Daerah (Perda) Syari 'ah Di Tasikmalaya," Asy-Syir'ah: Jurnal Ilmu Syari'ah dan Hukum 49, no. 1 (2015): 259-285.

${ }^{70}$ Kholid Mawardi, “Kolaborasi Manifestasi Komunikasi ‘Kiai Kampoeng' : Komunikasi Politik Kiai NU Masa Pendudukan Jepang," Komunika: Jurnal Dakwah dan Komunikasi 2, no. 2 (2008): 233-249.

${ }^{71}$ Hazim, "Riwayat Hidup."

72 Suryanegara, Api Sejarah 2. 
KH. Zainal Musthafa's rebellion motives were not only due to the cruelty and brutality of Japan but also to defend his religion. ${ }^{73}$ His motivation emerged from his awareness and conviction on how great his sin as ulama and santri if he saw injustice while did not launch any resistance. The courage of the santri grew because they had been convinced by the kiai that they did not seek victory in the battle. Instead, the battle is to uphold truth and justice. They were also taught about the beauty of falling at the battlefield as a martyr as Allah would place them in heaven and give noble provisions. $^{74}$

The rebellion of $\mathrm{KH}$. Zainal Musthafa and his santris towards the Japanese colonial gave huge influence in triggering Indonesian independence. ${ }^{75}$ However, due to the de-Islamization of historical writing in Indonesia, KH. Zainal Musthafa and the "golden kiai" were only written that they rebelled against the Japanese colonial for oppressing the farmers of Tasikmalaya Sukamanah. The social protest movement in demanding Indonesian independence based on Islam was not engraved. ${ }^{76}$

Furthermore, it is essential to observe the attitude of $\mathrm{KH}$. Zainal Musthafa in carrying out his struggle, namely his opposition to colonialism. His opposition attitude can be understood as daring to face one-by-one and being contradictory or opposing. KH. Zainal Musthafa's opposition attitude was orientated towards the interests of the ummah/people. In this case, his attitude was the actualization of the concept of amr bi al-ma'rüf wa nahyi an al-munkar. ${ }^{77}$ In further analysis, the emergence of national figures from pesantren who are able to move the people to fight the invaders was because of the kiai figures are pesantren

${ }^{73}$ Muhammad Husni, "Kondisi Umat Islam Masa Penjajahan Jepang," Jurnal Rihlah III, no. 1 (2015): 60-67.

74 Suryanegara, Api Sejarah 2.

75 "Pesantren Di Tasikmalaya," Www.Pstkhzmusthafa.or.Id (15/2/2014).

76 Suryanegara, Api Sejarah 2.

77 Sumardi, "Perjuangan KH. Zainal Musthafa 'Pertempuran Sukamanah Berdarah,'" Majalah Suara 'Ulama (Bandung, 2015). 
leaders who were highly respected and well-regarded, both by the pesantren community (santri) and the surrounding community. ${ }^{78}$

The above evidences are in line with the opinion of E.Z. Muttaqin (Former Chancellor of Bandung Islamic University). When he used to be a santri of Pesantren Sukamanah, he was assigned by $\mathrm{KH}$. Zainal Musthafa to deliver a letter to KH. Ahmad Sanusi in Pesantren Syamsul 'Ulum Gunung Puyuh Sukabumi. When he arrived at the Bandung train station, he was arrested by the Japanese army and taken to the kenpeitai headquarters at the Rumah Sakit Bungsu (now). As a spontaneous act, he swallowed the letter quickly. Suppose the letter arrived at KH. Ahmad Sanusi, there would also be solidarity in social protest at the Pesantren Gunung Puyuh Sukabumi. ${ }^{79}$ Based on the description above, it can be understood that the kiais have a large contribution and influence in leading the national movement.

$\mathrm{KH}$. Zainal Musthafa was able to instil noble values towards his santri and society. He is an ulama, fighter, and statesman who dares to be different for the sake of truth. He regularly preached, struggled and was prudent. He made unity and harmony priorities among the important factors in the struggle. His purpose was none other than the I'lā Kalimatillāh and the demolition of occupation and tyranny. ${ }^{80}$ Based on the values of tawhìd, Ghìrah Islämiyyah, rūh al-jihād, the discipline of aqīdah, there is no compromise with injustice, blunder in faith, and polytheism. Instead, the values promote to love the country, to dare to say the truth even it is bitter, stand against tyranny and oppression. Then it can be seen that the struggle of KH. Zainal Musthafa was built on a strong foundation so that victory was praiseworthy.

The values of the struggle of KH. Zainal Musthafa is currently actualized in the educational institution he established, namely the Pesantren KH. Zainal Musthafa Sukamanah. The values of tawhid and rūh al-jihād in the pesantren had been embedded since long

78 Ali Maulida, “Dinamika Dan Peran Pondok Pesantren Dalam Pendidikan Islam Sejak Era Kolonialisme Hingga Masa Kini," Edukasi Islami Jurnal Pendidikan Islam 05 (2016): 1295-1309.

79 Suryanegara, Api Sejarah 2.

${ }^{80}$ Edi Bukhori, "Peristiwa Perlawanan Sukamanah Dibangun Diatas Dasar Keagamaan Dan Kebangsaan Yang Kuat," Www.Pstkhzmusthafa.or.Id. 
time ago. Since the leadership of KH. Zainal Musthafa, the santri had been trained to gather in the mosque at 3 o'clock in the morning. Their ruhiyah prayers were fostered trough tahajjud prayer, istighfār, and several other practices. In other words, $\mathrm{KH}$. Zainal Musthafa had adopted the whole concept of jihad based on tawhìd to his students. ${ }^{81}$

Terminologically, the concept of jihad is understood as making best use of the physical and financial potential. As for jihad with the emphasis on optimizing the intellectual potential is called ijtihad. The concept of jihad in the meaning of optimizing the physical and financial potential had been fully understood by KH. Zainal Musthafa. As for the verse in the Qur'an, which is still used as the doctrine relating to the concept of jihad, is as follow:

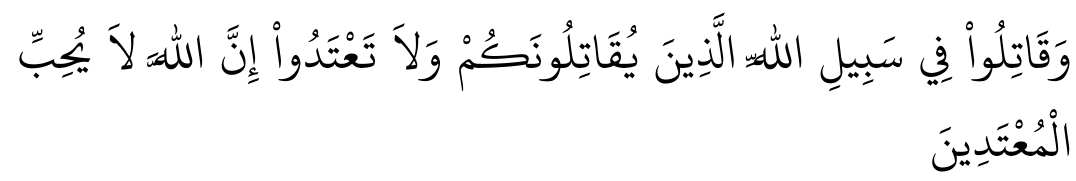

Fight in the way of Allah those who fight you but do not transgress. Indeed. Allah does not like transgressors. (QS. Al-Baqarah [2] : 190). ${ }^{82}$

The concept of jihad in terms of optimizing the intellectual potential had been practised since a long time ago. The santri of $\mathrm{KH}$. Zainal Musthafa had been coached with the mastery of the basic skills in the pesantren, such as the mastery of Arabic by memorizing the book of Alfiyah. The concept was reflection and actualization of the power of tafaqquh fi al-dìn, and was applied properly in every aspect of life including in jihad as it a doctrine in the Pondok Pesantren KH. Zainal Musthafa. ${ }^{83}$

The teaching methods at Pondok Pesantren KH. Zainal Musthafa emphasizes on the aspect of strengthening the aqidah (tașbìq al-'aqìdah), enlightening the heart and mind (tanwìr al-qalbi wa al-fikrah), and seeking solutions to various problems of the

${ }^{81}$ Nuryamin, "The Uniqueness of the Pesantren KH. Zainal Musthafa."

82 All the texts and translations of the Qoran in this article are quoted from Al-Quran in Word and validated by researchers with the printed edition of AlQuran dan Terjemahnya, translation by Tim Depag RI (Bandung: Diponegoro, 2015)

${ }^{83}$ Nuryamin, "The Uniqueness of the Pesantren KH. Zainal Musthafa." 
ummah (takhrij al-mas'alah al-ummah). ${ }^{84}$ This was as seen in the self of $\mathrm{KH}$. Zainal Musthafa when he witnessed tyranny, economic inequality, and occupation at that time; he was the ulama who was concerned the most.

Furthermore, KH. Zainal Musthafa was a scholar who loved science since the pesantren until now strongly emphasizes on the importance of tafaqquh fi al-din. Among the doctrines which are always emphasized is the following decree of Allah:

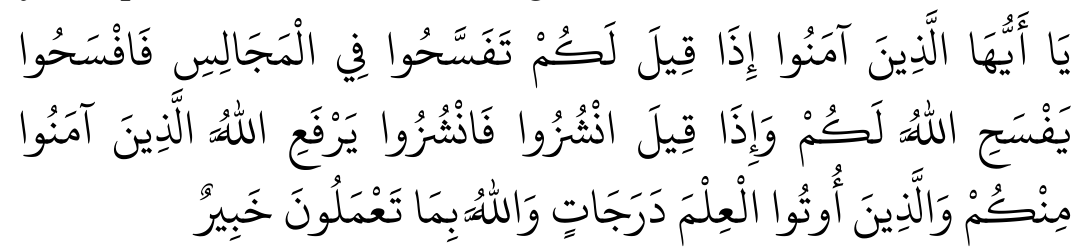

O you who have believed, when you are told, "Space yourselves" in assemblies, then make space; Allah will make space for you. And when you are told, "Arise," then arise; Allah will raise those who have believed among you and those who were given knowledge, by degrees. And Allah is Acquainted with what you do (QS. Al-Mujādalah [58] : 11). ${ }^{85}$

As for the hadith which is related to the primacy of the person who is fäqih fi al-dīn. The Prophet said:

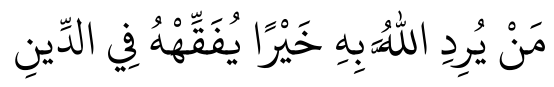

When Allah wishes suitable for someone, He bestows upon him the understanding of Deen. ${ }^{86}$

In relation to the love of science, the santri have been accustomed to learning based on literacy. At this point, Pesantren KH. Zainal Musthafa possesses uniqueness and characteristics, which are natural, scientific, and religious. On the other hand, adab (courtesy) has also been practised at the pesantren when the young generation today is experiencing a crisis of adab, especially to Allah, the Messenger, and fellow believers. ${ }^{87}$

Moreover, it has always been fostered at the pesantren that the young generation of Islam should never show apprehensiveness; instead, they must appear courageous and visionary. As for the

\footnotetext{
${ }^{84}$ Ibid.

85 "Aplikasi Quran in Word Versi 64 - 3.0."

86 “Aplikasi Gawami Al-Kalem Versi 4.5," 2018.

${ }^{87}$ Nuryamin, "The Uniqueness of the Pesantren KH. Zainal Musthafa."
} 
national context, KH. Zainal Mushtafa taught to love the homeland in an authentic sense which is not stained by the attitude of Ashobiyah since loving the homeland is a human's nature. Thus, the actualization of the struggle values of $\mathrm{KH}$. Zainal Musthafa appeared until now in the Pesantren KH. Zainal Musthafa's daily activities. ${ }^{88}$

Therefore, the organizers of any Islamic education institutions should follow KH. Zainal Musthafa as a pesantren leader in developing the education system. Pesantren plays an important part in a kiai's life. It is as a medium in which a kiai could broaden his influence with $d a^{\prime} w a h$. Therefore, the kiai could become a central force as well as the owner of institutions in developing Islamic education institutions. ${ }^{89}$ A good leader is a leader who is able to create sustainable change and has a broad understanding of his environment. ${ }^{90}$

Accordingly, the leaders of the pesantren must have qualities such as KH. Zainal Musthafa's, as they will give a significant influence on the character of their santris. Pesantren leaders who have robust Ghìrah Islämiyyah and rūh al-jihād will influence their santri, especially in terms of continuing the struggle of the pesantren in the future. Therefore, the figure of pesantren leaders must have strong values of tawhìd, tafaqquh fi al-dinn, Ghìrah Islamiyyah, rūh al-jihād, good manners, caring for the people, shajā'ah, țā'ah, determined, qan $\bar{a}^{\prime} a h$, charismatic, love his homeland, virtuous, willing to sacrifice, brave, visionary, against polytheism, immorality, occupation, oppression and tyranny.

The struggle values of $\mathrm{KH}$. Zainal Musthafa must be imitated by the pesantren leaders since at the present time pesantrens are lacking a brave role model who fights all forms of tyranny. Especially with regard to the problems that have plagued the people today, it is time for tafaqquh fi al-din pesantren leaders to give influence to the ummah by providing solutions to all life

${ }^{88}$ Ibid.

${ }^{89}$ Hatim Gazali and Abd Malik, "Pesantren and The Freedom of Thinking : Study of Ma' Had Aly Pesantren Sukorejo Situbondo, East Java, Indonesia," AlJami'ah 47, no. 2 (2009): 295.

${ }^{90}$ Nur Khusniyah Indrawati, “Management by Inspiration: Implementation of Transformational Leadership on Business at Pondok Pesantren*) Sunan Drajat," Procedia - Social and Behavioral Sciences 115 (2014): 79-90. 
problems that the ummah are facing. To name a few, the problems that are currently affecting the country involve expensive education, economic inequality, expensive health costs, the social life order impairment, law inequality and injustice, corruption, increasing rates of criminalization, etc.

Various problems that have occurred in this country have caused a decline in the nation's intellectual life. Therefore, pesantren leaders must take part in developing the nation's intellectual life as KH. Zainal Musthafa used to do. Today the nation is being colonized by the political system from all aspects of life; therefore the pesantren leaders must be present to enlighten and liberate the nation from the problems by optimizing their roles through the pesantren they lead.

Based on the description above, pesantren leaders have a very central role in developing pesantren since the improvement of pesantren. It can be seen from the figure of their leaders who will determine various policies in the pesantrens they lead. On the other hand, the pesantren leaders are the teachers who will be imitated and become an inspiration for their santris. Therefore, the pesantren leaders must have the values of struggle as possessed by $\mathrm{KH}$. Zainal Musthafa. To make the struggle values of $\mathrm{KH}$. Zainal Musthafa easier to understand, the authors made a chart as follows:

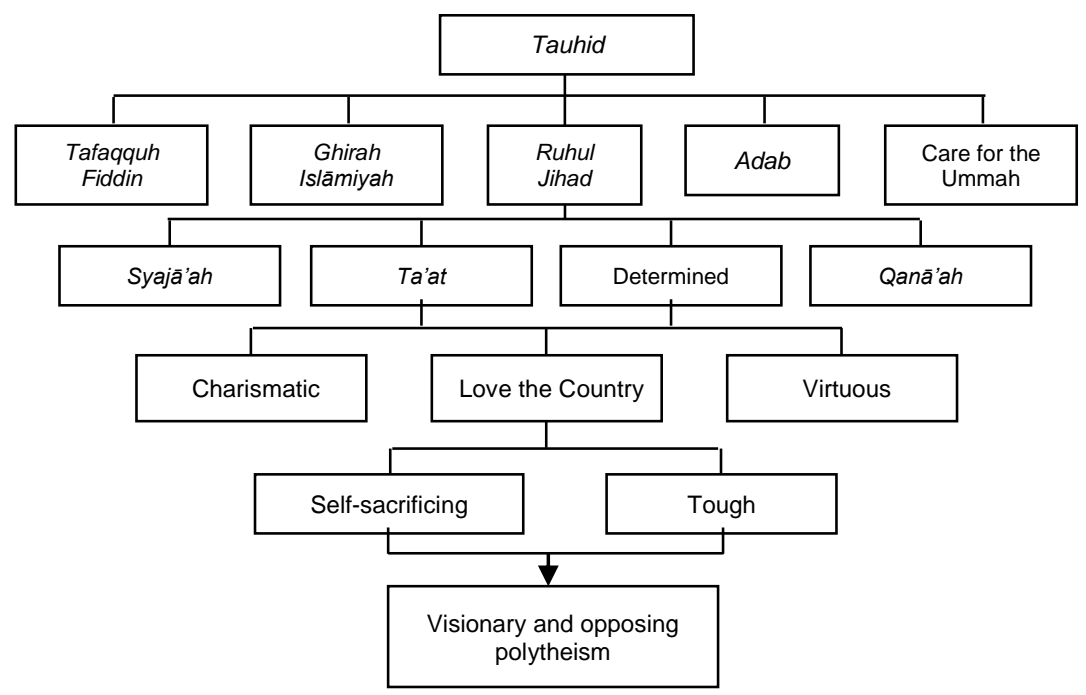

Chart 5. The Struggle Values of KH. Zainal Musthafa 


\section{Conclusion}

$\mathrm{KH}$. Zainal Musthafa was an ulama, fighter, leader, statesman, and role model for the ummah. KH. Zainal Musthafa always sustained the values of a strong tawhìd, tafaqquh fi al-dīn, Ghìrah Islamiyyah, rūh al-jihād, adab, caring for the ummah, shajā'ah, ță'ah, determined, qana' $a h$, charismatic, loving his homeland, virtuous, self-sacrificing, tough, visionary, and opposed polytheism, immorality, occupation, oppression, and injustice. The motivation of his struggle emerged from the awareness and conviction against the practice of polytheism, colonialism, oppression, injustice and inequality. Thus, the motive for his struggle is based on the values of tawhìd and the demand for Indonesian independence based on Islam.

Pesantren KH. Zainal Musthafa Sukamanah is an evidence of his legacy and as a means of struggle to liberate the Indonesian people from ignorance, slavery, poverty, oppression and injustice by developing the intellectual life of the nation through the educational institution. These values are derived from Islamic teaching and are developed through pesantren. The actualization of the values remain essential to bring further the country into justice, literate and prosperity.

\section{Reference}

Adeng. "Pesantren Cipasung di Bawah Kepemimpinan K.H. Ruhiat (Studi Keterlibatan Kiai Dalam Perjuangan Kemerdekaan)." Patarjala 6, no. 2 (2014): 253-268.

Amaliah, Ima, Tasya Aspiranti, and Pupung Purnamasari. “The Impact of the Values of Islamic Religiosity to Islamic Job Satisfaction in Tasikmalaya West Java, Indonesia, Industrial Centre." Procedia - Social and Behavioral Sciences 211, no. September (2015): 984-991.

Anam, Saeful. "Karakteristik dan Sistem Pendidikan Islam:

Mengenal Sejarah Pesantren, Surau, dan Meunasah di Indonesia." Jalie: Journal of Applied Linguistics and Islamic Education 1, no. 1 (2017): 146-149. 
Bukhori, Edi. "Peristiwa Perlawanan Sukamanah Dibangun Diatas Dasar Keagamaan Dan Kebangsaan Yang Kuat." Www.Pstkhzmusthafa.or.Id.

Darnela, Lindra. "Tinjauan Sistem Hukum Dalam Penerapan Peraturan Daerah (Perda) Syari 'ah Di Tasikmalaya." AsySyir'ah: Jurnal Ilmu Syari'ah dan Hukum 49, no. 1 (2015): 259285.

Gazali, Hatim, and Abd Malik. "Pesantren and The Freedom of Thinking: Study of $\mathrm{Ma}^{\prime}$ Had Aly Pesantren Sukorejo Situbondo, East Java, Indonesia." Al-Jami'ah 47, no. 2 (2009): 295.

Haki, Nurul, and Suhartono. "Perubahan Sosial Pesantren di Tasikmalaya Pada Paruh Pertama Abad Ke-20 (1905-1950)." Jurnal Humanika 17, no. 3 (2004): 341-354.

Hakim, Lukman. "Kifrah KH. Zenal Mustofa terhadap

Perkembangan Pendidikan Islam di Sukamanah Singaparna Tasikmalaya." Tekno Efisiensi 2, no. 1 (2017): 137-142.

Hamzah, Syeh Hawib. "Perkembangan Pesantren di Indonesia." Syamil 2, no. 1 (2014): 1-14.

Hardiana, Yanyan. "Pembelajaran Sejarah Indonesia Berbasis Peristiwa-Peristiwa Lokal di Tasikmalaya untuk

Meningkatkan Kemampuan Berpikir Kritis." Historia: Jurnal Pendidik dan Peneliti Sejarah I, no. 1 (2017): 41-46.

Hazim, Yusuf. “Intervew: Riwayat Hidup Pahlawan Nasional KH. Zainal Musthafa," 2017.

- - - Pedang Bambu Peninggalan Pasukan KH. Zainal Musthafa. Tasikmalaya, 2017.

Hidayat, Syarief. Kisah Nyata Sebelum dan Sesudah Indonesia Merdeka Riwayat Perjuangan dari Pemberontakan Sukamanah sampai Prajurit Sapta Marga. Tasikmalaya: Dinas Dikbud SLTP KHZ Musthafa, 1996.

Hidayat, Tatang, and Abas Asyafah. "Paradigma Islam dalam Metodologi Penelitian dan Implikasinya terhadap Penelitian Pendidikan Agama Islam." Tadrib IV, no. 2 (2018): 225-245.

Hidayat, Tatang, Ahmad Syamsu Rizal, and Fahrudin. "Peran Pondok Pesantren Sebagai Lembaga Pendidikan Islam di Indonesia." Ta'dib: Jurnal Pendidikan Islam VII, no. 2 (2018): 115. 
Husni, Muhammad. "Kondisi Umat Islam Masa Penjajahan Jepang." Jurnal Rihlah III, no. 1 (2015): 60-67.

Indrawati, Nur Khusniyah. "Management by Inspiration: Implementation of Transformational Leadership on Business at Pondok Pesantren*) Sunan Drajat." Procedia - Social and Behavioral Sciences 115 (2014): 79-90.

Maulida, Ali. "Dinamika Dan Peran Pondok Pesantren Dalam Pendidikan Islam Sejak Era Kolonialisme Hingga Masa Kini." Edukasi Islami Jurnal Pendidikan Islam 05 (2016): 1295-1309.

Mawardi, Kholid. “Kolaborasi Manifestasi Komunikasi 'Kiai Kampoeng' : Komunikasi Politik Kiai NU Masa Pendudukan Jepang." Komunika: Jurnal Dakwah dan Komunikasi 2, no. 2 (2008): 233-249.

Muaffan, Abdi. "Singa Tasikmalaya." Www.Pstkhzmusthafa.or.Id. Tasikmalaya, 2018.

Muhsin, Fuad. Sekilas Riwayat Hidup dan Perjuangan Pahlawan Nasional Asy-Syahid KH. Zainal Musthafa. Tasikmalaya: Pondok Pesantren Sukamanah Tasikmalaya, 2010.

Musthafa, Izzuddin, Dedih Wahyudin, and Betty Tresnawaty. "The People Empowerment Pattern In Pesantren Environment: A Case Study about Community Around Pesantren in West Java, Indonesia." Advances in Social Science, Education and Humanities Research 143, no. November (2017): 53-33.

Musthofa. "Kedatangan Islam dan Pertumbuhan Pondok Pesantren di Indonesia Perspektif Filsafat Sejarah." An-Nuha 2, no. 1 (2015): 1-15.

Nasir, Mohamad Abdun. "Islam, Historical Representation and Muslim Autobiography in the Indonesian New Order." Studia Islamika 18, no. 1 (2014): 67-100.

Nopianti, Risa. "Pendidikan Akhlak Sebagai Dasar Pembentukan Karakter di Pondok Pesantren Sukamanah Tasikmalaya." Patanjala 10, no. 2 (2018): 251-266.

Nuryamin, Anwar. "The Uniqueness of the Pesantren KH. Zainal Musthafa Sukamanah Tasikmalaya in Islamic Boarding School Education Organize," March 27, 2019.

Risdiana, Aris. "Budaya Organisasi Pondok Pesantren Berbasis NU dan Persis Benda 67 di Tasikmalaya Jawa Barat." 
Aplikasia: Jurnal Aplikasi Ilmu-Ilmu Agama 16, no. 2 (2016): 7383.

Sumardi. "Perjuangan KH. Zainal Musthafa 'Pertempuran Sukamanah Berdarah.'” Majalah Suara 'Ulama. Bandung, 2015.

Suryanegara, Ahmad Mansyur. Api Sejarah 2. Bandung: Salamadani, 2014.

Wahid, Acep. "Perjuangan Pahlawan Nasional KH. Zainal Musthafa (Wawancara Bersama Acep Wahid)," 2017.

Wekke, Ismail Suardi, and Sanusi Hamid. "Technology on Language Teaching and Learning: A Research on Indonesian Pesantren." Procedia - Social and Behavioral Sciences 83 (2013): 585-589.

“Aplikasi Gawami Al-Kalem Versi 4.5," 2018.

“Aplikasi Quran in Word Versi 64 - 3.0," 2018.

Brosur Pondok Pesantren KH. Zainal Musthafa Sukamanah. Tasikmalaya, 2017.

"Film Asy-Syahid KH. Zainal Musthafa." Www.Pstkhzmusthafa.or.Id.

“Gambar KH. Zainal Musthafa.” Tasikmalaya, 2017.

Pedang Peninggalan Kerajaan Mataram Islam. Tasikmalaya: TIdak dipublikasikan, 2017.

Pribadi, Dokumentasi. Taman Makam Pahlawan KH. Zainal Musthafa Sukamanah. Tasikmalaya, 2017.

"Pesantren Di Tasikmalaya." Www.Pstkhzmusthafa.or.Id (15/2/2014).

"Profil Pondok Pesantren KH. Zainal Musthafa Sukamanah Tasikmalaya." Www.Pstkhzmusthafa.or.Id. 